\title{
Emerging epidemics
}

\section{We have no one but ourselves to blame for the rise of new killer diseases.}

\section{Six Modern Plagues: And How We are Causing Them \\ by Mark Jerome Walters \\ Island Press: 2003. 206 pp. \$22 \\ Tony McMichael}

The word 'plague' has a profound historical, even biblical, resonance. In 1976, the historian William McNeill wrote his seminal book Plagues and Peoples, which explored how the emergence and spread of infectious diseases over millennia has reflected changes in human culture, demography and contact patterns. Since then, various other plague books - notably Laurie Garrett's The Coming Plague (Virago, 1995), Arno Karlen's Plague's Progress (Orion, 1995) and Plagues by Christopher Wills (Diane, 1996) - have appeared. Now we have Six Modern Plagues by Mark Walters.

Refreshingly, this latest book explores the underlying shifts in human ecology and behaviour that have potentiated recent epidemics. We are spared the usual combative clichés about conquering the microbes, being under siege and counter-attacking. Walters draws out of each example the fundamental lesson that, as we continue to change our ways of living, our environmental encroachments, our long-distance contacts and our food production methods, so we create opportunities for the genetically fleet-footed microbial world. Their drive to survive is as strong as ours, and is based on much longer experience.

Walters has selected six modern plagues from a list of several dozen infectious diseases that have appeared in human populations over the past three decades. As has been widely remarked, this is a very rapid rate of disease emergence. It reflects just how much modern humans have intensified our disturbance of, and interaction with, the natural world and its microbial multitudes. Walters quotes Peter Daszak, a leading conservation medicine researcher, as saying: "Show me almost any new infectious disease, and I'll show you an environmental change brought about by humans that either caused or exacerbated it."

Four of the featured infectious diseases - Lyme disease, Hantavirus pulmonary syndrome, West Nile fever and now mad cow disease (bovine spongiform encephalopathy, or BSE) - have recently emerged in the United States. The book also covers antibioticresistant Salmonella DT104, and HIV/AIDS. All six, says Walters, are "parables of the unintended consequences of careless human disruption of the natural systems that are our home". The emergence of Salmonella

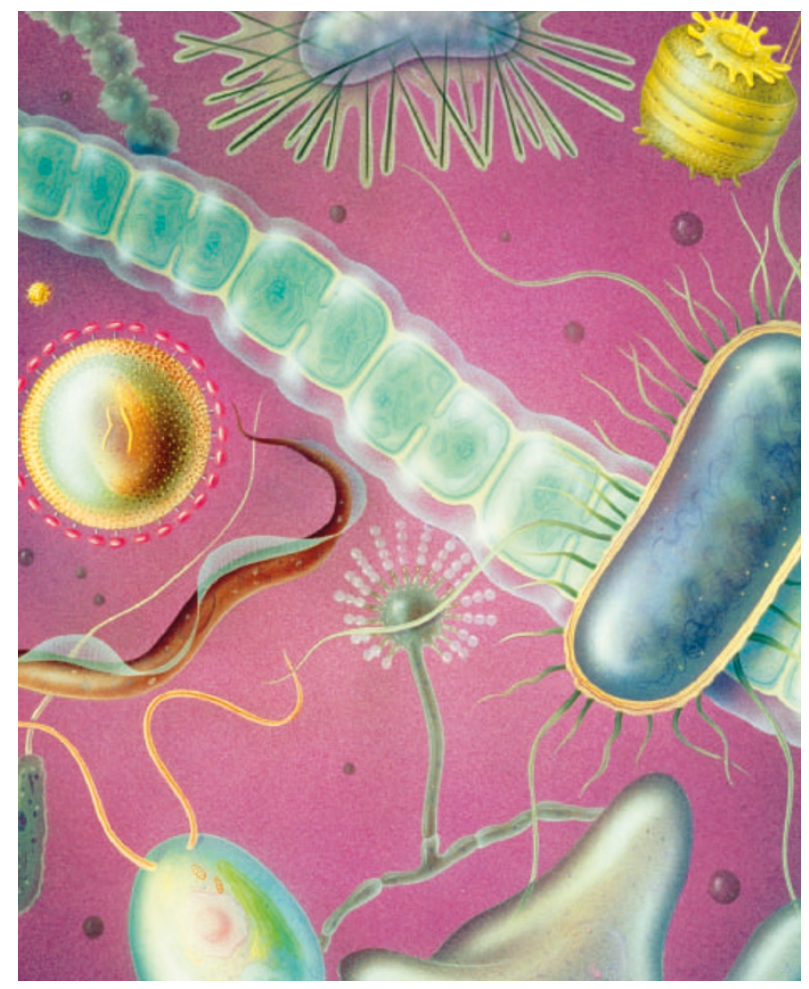

Little cause for concern? Deadly diseases come in small packages.

DT104 and many other antibiotic-resistant bacteria has resulted from our injudicious use of antibiotics to enhance the force-fed growth of livestock - a practice that the US government, in particular, has been reluctant to curb because of vested interests and the commitment to market economics.

Mad cow disease emerged as a bizarre plague in British cattle in 1986. It subsequently transpired that the cause was bovine cannibalism, as rendered meat and bone meal from slaughtered sheep and cows were fed to cows as a protein supplement. The infective agent, a misshapen protein molecule (a prion) that imposes its peculiar molecular origami on other such proteins in the brain, causes neurological damage. It also affects human consumers of beef, causing variant Creutzfeldt-Jakob disease. The number of human cases, currently about 130 , is several orders of magnitude fewer than the several million cows infected and culled.

Walters achieves a balance between environmental science, clinical medicine, human interest and social comment. The style is recognizably American, with each chapter presenting, in Time magazine fashion, a personalized illustration of a typical case of the disease in question. We meet, among others, a troubled UK dairy farmer; several young American deer-hunters who get a relative of mad cow disease from eating affected venison (chronic wasting disease in deer); an HIVinfected chimp called Amandine; a Vermont cattle farmer at the point of death from Salmonella DT104; and a university student in New Jersey who caught Lyme disease from a tick lurking in the bushes around his frisbee arena.

Walters' book does not lead to specific prescriptive recommendations. Rather, he argues, insight into the underlying ecological processes that enhance microbial opportunism will enable us to tackle the roots of the problem, by "restoring the ecological wholeness upon which our health often depends".

In contrast to Walters' book is The New Killer Diseases by Elinor Levy and Mark Fischetti (Crown, 2003). Judging this book by its cover, it clearly is about Us and Them. The back cover states: "All around us - in our homes, workplaces, and public spaces - bacteria and viruses are evolving at a feverish rate, and our best defenses against them are in danger of being overwhelmed. The threat posed by emerging diseases is as formidable as any threat the human race has ever faced." The great challenge, it seems, is "to beat back the microbe armies".

Much of the book evinces this same idiom, telling us, for example, that "among the sinister threats we face in the pathogen war are deadly germs that infiltrate from abroad". And: "Just as with bacteria, killer viruses lurk everywhere, and they are even more cunning." This misconstrues the microbes' purpose. Microbes are interested only in enhancing their own survival and reproduction; they have no malign design on us. So, despite this book's lively accounts of recent outbreaks of infectious disease, suffused with human interest and lurid clinical detail, it fails to explain why infectious diseases are emerging or spreading at an increased rate in today's world. For that, see Walters'book.

Tony McMichael is at the National Centre for Epidemiology and Population Health,

The Australian National University, Canberra, ACT 0200, Australia. 